\section{Productive evaluation of dairy cows fed with urea protected by protein nanoparticle in partial replacement of soybean meal}

\author{
Avaliação produtiva de vacas \\ leiteiras alimentadas com ureia \\ protegida por nanopartículas \\ proteicas em substituição \\ parcial ao farelo de soja
}

\author{
Deivid Roni Ribeiro (1* \\ José Leonardo Sviech Ratim (1) 1 \\ Kauane Maria Ribeiro (1D ${ }^{2}$ \\ Rodrigo de Almeida (D) ${ }^{2}$ \\ André Ostrensky (iD ${ }^{1}$ \\ Amanda Anater $\mathbb{B}^{1}$ \\ Cláudia Turra Pimpão (1) ${ }^{1}$
}

\author{
1 Pontifícia Universidade Católica do Paraná (PUCPR), School of \\ Life Sciences, Curitiba, PR, Brazil \\ ${ }^{2}$ Universidade Federal do Paraná (UFPR), Sector of Agricultural \\ Sciences, Curitiba, PR, Brazil \\ * Correspondence: deividrr@hotmail.com \\ Received: 2021 Feb 20 | Approved: 2021 Jun 8 \\ DOI: http://dx.doi.org/10.7213/acad.2021.19007 \\ Rev. Acad. Ciênc. Anim. 2021;19:e19007
}

\begin{abstract}
The objective of this study was to evaluate productive and metabolic responses of dairy cows fed a diet with urea protected by protein nanoparticles. The experimental design was a crossover with three groups of 15 cows each and three periods of 21 days. In each period the animals were fed one of the isonitrogenated and isocaloric diets: $\mathrm{SM}=$ without substitution of soybean meal; $\mathrm{CU}$ $=$ substitution of soybean meal by $0.52 \%$ conventional
\end{abstract}

urea; $\mathrm{PU}=$ soybean meal substituted by $0.59 \%$ urea protected by nanoparticles. The yield and composition of milk, the blood and urine biochemical parameters, as well the allantoin:creatinine ratio as a predictor of microbial protein absorption were measured. No significant differences were found ( $p>0.05$ ) in milk yield and composition, in urinary biochemistry and in allantoin:creatinine ratio. The average values of plasma ureic nitrogen (PUN) in mg.dL-1 after the morning feeding did not differ significantly $(p>0.05)$ in the $C U$ (20.65) and PU (20.25), but both were higher ( $p<0.05)$ when compared to SM (19.52). Inclusions of $0.59 \%$ urea protected by nanoparticles do not affect the productive performance of dairy cows. The similar values of PUN between the treatments $\mathrm{CU}$ and PU suggest that the behavior of the release and the absorption of ammonia in the rumen is similar between these two types of urea which were evaluated, but the use of ground corn is important to reach these results.

Keywords: Allantoin. Milk composition. Milk yield. Nitrogen excretion. Non-protein nitrogen. 


\section{Resumo}

O objetivo deste estudo foi avaliar parâmetros produtivos e metabólicos de vacas leiteiras alimentadas com ureia protegida por nanopartículas. O delineamento foi um crossover, com três grupos de 15 vacas cada e três períodos de 21 dias. Em cada período os animais foram alimentados com uma das três dietas isonitrogenadas e isoenergéticas: $F S$ = sem substituição do farelo de soja; $U C=$ substituição parcial do farelo de soja por $0,52 \%$ de ureia convencional; UP = substituição parcial do farelo de soja por 0,59\% de ureia protegida por nanopartículas. Foram mensuradas a produção e composição do leite, parâmetros de bioquímica sanguínea e urinária, além da relação alantoína:creatinina urinária como preditor da absorção de proteína microbiana. Não foram encontradas diferenças significativas $(p>0,05)$ na produção e composição do leite, na bioquímica urinária ou na relação alantoína:creatinina. Os valores médios de nitrogênio ureico no plasma (NUP) em $\mathrm{mg} \mathrm{dL}^{-1}$ após a alimentação matinal não diferiram significativamente ( $p$ $>0,05)$ no UC $(20,65)$ e UP $(20,25)$, porém ambos foram maiores $(p<0,05)$ quando comparados ao FS $(19,52)$. A inclusão de 0,59\% de ureia protegida por nanopartículas não afeta o desempenho produtivo de vacas em lactação. Os valores de NUP semelhantes entre os tratamentos UC e UP sugerem que o comportamento de liberação e de absorção de amônia no rúmen é similar entre essas duas formas de ureia testadas, entretanto o uso de milho moído é importante para alcançar esses resultados.

Palavras-chave: Alantoína. Composição do leite. Excreção de nitrogênio. Nitrogênio não proteico. Produção de leite.

\section{Introduction}

Ruminants have an important characteristic in nitrogen ( $\mathrm{N}$ ) metabolism, since they are able to use non-protein nitrogen sources (NPN); that is, they use $\mathrm{N}$, which is not integrating in a protein molecule and may be in the form of urea, ammonia, nucleic acids, nitrates and nitrites (Kozloski, 2011). This ability is due to the fact that part of the ruminal microorganisms uses ammonia as a substrate for the synthesis of their own amino acids.

Urea is the main source of NPN added to ruminant feed (Gabarra, 2001) and has values of $N$ close to $45 \%$ (Santos et al., 2001), giving to it a protein equivalent value of approximately $281 \%$. Its use has been recommended since the 1950s, when the first recommendations were made for inclusion in dairy cows (Reid, 1953). In general, recommended inclusion values should not exceed $1 \%$ of dietary dry matter (DM) (Santos et al., 2011).

However, its characteristic of rapid ruminal hydrolysis with the release of large amounts of ammoniacal N in the rumen (Golombeski et al., 2006; Highstreet et al., 2010) can be a disadvantage, having a great importance in the decision of urea use. Overall, the release of ammonia occurs at a faster rate than the assimilation capacity by the ruminal bacteria, resulting in escape of ammoniacal $\mathrm{N}$ to the bloodstream through the ruminal epithelium (Lapierre and Lobley, 2001).

In the bloodstream, the ammonia is carried out into the liver and is transformed into urea through the urea or ornithine cycle, which has energy expenditure since there is burn of high energy phosphate bonds (Nelson and Cox, 2004).

A possible adverse effect of the inappropriate usage of urea is related to the toxic potential of ammonia on the nervous system (Visek, 1968), causing tetany, tympanism, sialorrhea and dyspnea. In addition, excessive levels of plasma urea are also related to be harmful to reproductive performance (Rajala-Schultz et al., 2001; Rhoads et al., 2006).

Another adverse effect is that the excess of ammonia in the rumen could lead to a reduction in nitrogen use efficiency (NUE) in dairy cows, inducing an environmental problem because the excess of $\mathrm{N}$ is excreted by feces and urine (Spek et al., 2013). The term NUE describes the proportion of ingested $\mathrm{N}$ that is secreted in milk as crude protein (Mutsvangwa et al., 2016), and generally the bigger the NUE, the better.

Brito and Broderick (2007) and Highstreet et al. (2010), working with conventional urea for lactating cows, showed negative impacts on productive performance, with decreases in milk production and also in fat, protein and lactose productions, as well as a decrease in protein content in milk and $10 \%$ decrease in feed efficiency. Santos et al (2011) also demonstrated an increase in milk urea nitrogen (MUN) when cows were fed with conventional urea, since MUN is directly related to plasma urea levels (Hof et al., 1997). 
Thus, urea protected from ruminal degradation may be an alternative to conventional urea because through a slower release of urea and consequently less free ammonia in the rumen, it allows a better use of $\mathrm{N}$ by ruminal bacteria (Galo et al., 2003).

The hypothesis of the present study is that the use of urea protected by protein nanoparticles in the diet of dairy cows does not affect milk production and milk composition of these animals.

This study aimed to evaluate the productive performance and blood parameters related to nitrogen metabolism in dairy cows fed a diet in which soybean meal was partially replaced by urea protected by protein nanoparticles resistant to thermal processing.

\section{Material and methods}

This trial was approved by the Ethics Committee on Use of Animals of the Pontifícia Universidade Católica do Paraná (PUCPR) (Brazil), under protocol number 888 - 1st version. It was carried out in the Dairy Cattle Sector of the Gralha Azul Experimental Farm of PUCPR. Forty five Holstein dairy cows with $170 \pm$ 87 days in milk, $1.9 \pm 0.9$ lactations, and average milk yield of $34.9 \pm 5.9 \mathrm{~kg} \cdot \mathrm{d}^{-1}$ were enrolled in the study. The cows were milked twice daily $(6$ am and $6 \mathrm{pm})$ and housed in a free-stall barn.

Cows were blocked in three different groups according to the lactation, days in milk and milk yield. The design was a crossover and the animals from each block received simultaneously one of the three treatments during 21 consecutive days, the treatments being alternated between the groups at the end of each period of 21 days.

The treatments were: soybean meal (SM), diet without soybean meal substitution; conventional urea (CU), diet with partial replacement of soybean meal by conventional urea; and protected urea (PU), with partial replacement of soybean meal by urea protected by protein nanoparticles. The material used to protect this urea is composed by protein nanoparticles that are thermo resistant. The technology used to manufacture this coating is not described by the company.

The basal diet was provided as a total mixed ration (TMR) (Table 1), twice daily, immediately after milking at 6 am and $6 \mathrm{pm}$, in a feed bunker with selflocking system. The top-dressing treatment was given on the morning diet because the urea supply in the afternoon may decrease the ammonia absorption through the ruminal epithelium, due to the lower ruminal pH in that period (Santos et al., 2011), thus masking possible detrimental effects of both ureas.

Table 1 - Composition of the basal diet and the complements of each treatment

\begin{tabular}{|c|c|c|c|}
\hline Ingredients (\%DM) & \multicolumn{3}{|c|}{ Basal diet } \\
\hline Corn silage & \multicolumn{3}{|c|}{43.07} \\
\hline Tifton hay & \multicolumn{3}{|c|}{1.46} \\
\hline Soybean meal & \multicolumn{3}{|c|}{13.01} \\
\hline Ground corn & \multicolumn{3}{|c|}{15.93} \\
\hline Wheat bran & \multicolumn{3}{|c|}{8.33} \\
\hline Wet brewery residue & \multicolumn{3}{|c|}{6.47} \\
\hline Soybean hull & \multicolumn{3}{|c|}{3.73} \\
\hline Limestone & \multicolumn{3}{|c|}{1.15} \\
\hline Sodium bicarbonate & \multicolumn{3}{|c|}{1.05} \\
\hline Mineral mix ${ }^{1}$ & \multicolumn{3}{|c|}{1.04} \\
\hline Calcium salts of fatty acids & \multicolumn{3}{|c|}{0.60} \\
\hline Magnesium oxide & \multicolumn{3}{|c|}{0.22} \\
\hline Sodium chloride & \multicolumn{3}{|c|}{0.22} \\
\hline Dicalcium phosphate & \multicolumn{3}{|c|}{0.09} \\
\hline $\begin{array}{l}\text { Trace minerals and vitamins } \\
\text { premix }^{2}\end{array}$ & \multicolumn{3}{|c|}{0.09} \\
\hline Mycotoxin adsorbent & \multicolumn{3}{|c|}{0.09} \\
\hline \multirow[t]{2}{*}{ Ingredients (\%DM) } & \multicolumn{3}{|c|}{$\begin{array}{c}\text { Complement in feed } \\
\text { bunker }\end{array}$} \\
\hline & SM & $\mathrm{CU}$ & $\mathrm{PU}$ \\
\hline Soybean meal & 3.45 & - & - \\
\hline Ground corn & - & 3.24 & 3.24 \\
\hline Conventional urea & - & 0.52 & - \\
\hline Protected urea & - & - & 0.59 \\
\hline
\end{tabular}

Note: $\mathrm{DM}=$ dry matter; $\mathrm{SM}=$ treatment without replacement of soybean meal; $\mathrm{CU}=$ treatment with partial replacement of soybean meal by conventional urea; $P U=$ treatment with partial replacement of soybean meal with protected urea. ${ }^{1}$ Guarantee levels of mineral mix: Ca: $19.8 \mathrm{~g} \cdot \mathrm{kg}^{-1}$; P: $6.0 \mathrm{~g} \cdot \mathrm{kg}^{-1} ; \mathrm{K}: 1.0 \mathrm{~g} \cdot \mathrm{kg}^{-1} ; \mathrm{S}: 1.5 \mathrm{~g}^{\mathrm{kg}}{ }^{-1} ; \mathrm{Na}: 8.0$ g.kg-1 $\mathrm{Cl}^{-1} 12.0$ g.kg ${ }^{-1}$ Mg: 2.0 g.kg-1; Co: 50 ppm; Cu: 700 ppm; Fe: 1600 ppm; l: 70 ppm; Mn: 1800 ppm; Se: 22 ppm; Zn: 2800 ppm; Vitamin A: 170,000 Ul.kg ${ }^{-1}$; Vitamin D: 50,000 Ul.kg ${ }^{-1}$; Vitamin E: 850 UI. $\mathrm{kg}^{-1} \cdot{ }^{2}$ Guarantee levels of trace minerals premix $=$ Co: 680 ppm; Cu: 2035 ppm; I: 815 ppm; Mn: 40.71 ppm; Se: 615 ppm; Zn: 95 ppm; Vitamin A: 7,200,000 Ul.kg-1 ${ }^{-1}$ Vitamin D: 2,150,000 Ul.kg ${ }^{-1}$; Vitamin D: 46,830 Ul.kg-1; Biotin: 1,460 ppm; Monensin: 20,3 g.kg-1. 
As complement to the basal diet, soybean meal and ground corn were added on the TMR already in the feed bunker in order to maintain the treatments diets with the same DM beyond keep them isocaloric and isonitrogenated.

The ration was formulated according to the levels recommended by NRC Dairy Cattle (2001) (Table 2). TMR was supplied in sufficient quantity to $5 \%$ of leftovers at the end of the day.

The chemical composition of the basal diet in each of the periods is described in Table 3. It can be observed that there is an increase in the crude protein $(\mathrm{CP})$ content in relation to the formulated values (Table 2), however these variations were constant during the periods, providing similar protein levels for both groups over the course of the experimental period.

Prior to the provision of treatments, a covariate period with milk yield measurement was performed for three consecutive days with the purpose of group division. On days 17, 18 and 19 of each period milk yield was measured and samples of milk were taken and analyzed for contents of fat, protein, lactose, casein, milk urea nitrogen (MUN), total solids and somatic cell count (SCC). The yields in $\mathrm{kg} \cdot \mathrm{d}^{-1}$ of each component of the milk were calculated, as well as the milk yield in $\mathrm{kg} . \mathrm{d}^{-1}$ corrected for energy and corrected to $3.5 \%$ fat, besides the energy excreted in milk in Mcal.d $\mathrm{d}^{-1}$ (Boermann et al., 2015) and the excretion in g.dia- ${ }^{-1}$ of MUN.

Table 2 - Estimated nutritional levels of experimental diets with the addition of respective supplements, formulated according to NRC Dairy Cattle ${ }^{1}$

\begin{tabular}{lccc}
\hline \multirow{2}{*}{ Nutritional levels (\%DM) } & \multicolumn{3}{c}{ Experimental diets } \\
\cline { 2 - 4 } & SM & CU & PU \\
\hline Dry matter (\%OM) & 48.18 & 48.19 & 48.30 \\
Crude protein & 15.90 & 15.90 & 15.90 \\
Rumen degradable protein & 10.50 & 11.00 & 10.40 \\
Rumen non-degradable protein & 5.40 & 4.90 & 5.50 \\
RDP balance (g.d ${ }^{-1}$ ) & 148.00 & 258.00 & 124.00 \\
RUP balance (g.d -1) $^{-1}$ ) & 142.00 & 39.00 & 188.00 \\
Neutral detergent fiber & 34.20 & 33.80 & 33.80 \\
Forage neutral detergent fiber & 21.50 & 21.40 & 21.40 \\
Acid detergent fiber & 19.20 & 18.90 & 18.90 \\
Ethereal extract & 4.00 & 4.10 & 4.10 \\
Non-fibrous carbohydrates & 40.10 & 40.60 & 40.70 \\
Total digestible nutrients for cattle & 71.00 & 71.00 & 71.00 \\
Calcium & 0.90 & 0.90 & 0.90 \\
Phosphorus & 0.50 & 0.50 & 0.50 \\
Average consumption (kg.d ${ }^{-1}$ ) & & & \\
Estimated consumption of OM & 49.39 & 49.52 & 49.39 \\
Estimated consumption of DM & 23.80 & 23.91 & 23.80 \\
Estimated consumption of CP & 3.78 & 3.80 & 3.78 \\
Estimated consumption of $\mathrm{N}^{2}$ & 0.60 & 0.60 & 0.60 \\
\hline
\end{tabular}

Note: $\mathrm{SM}=$ treatment without replacement of soybean meal; $\mathrm{CU}=$ treatment with partial replacement of soybean meal by conventional livestock urea; $\mathrm{PU}=$ treatment with partial replacement of soybean meal with protected urea; $\mathrm{DM}=$ dry matter; $\mathrm{OM}=$ original matter; $\mathrm{CP}=$ crude protein; $\mathrm{N}=$ nitrogen; RDP = rumen degradable protein; RUP = rumen undegradable protein. ${ }^{1}$ Nutritional levels generated through the requirements of NRC Dairy Cattle (2001), using the following parameters: lactating cows, $35.5 \mathrm{~kg} . \mathrm{d}-1$ daily milk production, Holstein, 42 months of age, $660 \mathrm{~kg}$ live weight, $3.4 \%$ milk fat, $2.88 \%$ milk true protein, 140 days lactation and 60 days of pregnancy. ${ }^{2}$ Consumption of CP.d ${ }^{-1} \times 0.46$. 
Table 3 - Nutritional composition of the basal diet of each of the experimental periods

\begin{tabular}{lccc}
\hline \multirow{2}{*}{ Nutritional levels (\%DM) } & \multicolumn{3}{c}{ Basal diets } \\
\cline { 2 - 4 } & 1stP & 2nd P & 3rd P \\
\hline Dry matter (\%OM) & 44.80 & 44.50 & 45.15 \\
Crude protein & 16.61 & 16.80 & 16.60 \\
Neutral detergent fiber & 36.01 & 31.65 & 30.77 \\
Acid detergent fiber & 16.00 & 13.19 & 12.34 \\
Ether extract & 4.03 & 4.07 & 3.99 \\
Ash & 5.43 & 5.49 & 5.48 \\
Non-fibrous carbohydrates & 37.92 & 41.99 & 43.16 \\
Calcium & 1.57 & 1.44 & 1.36 \\
Phosphorus & 0.39 & 0.38 & 0.39 \\
\hline
\end{tabular}

Note: $\mathrm{DM}=$ dry matter; $\mathrm{OM}=$ original matter $\mathrm{P}=$ period

On the 21st day of each period, individual blood samples were collected from the 15 cows per group. The blood was collected in vacuum tubes (Vacuette ${ }^{\circledR}$ ) with clot activator (one sample for serum) or anticoagulant (seven samples for plasma) and then centrifuged for $15 \mathrm{~min}$ at 3,500 RPM; the supernatant was removed and packed in microtubes and frozen at $-20^{\circ} \mathrm{C}$ for further analysis.

The serum sample was collected at the time of morning feeding (TO) and plasma samples were collected at seven different times throughout the entire day: at $0,1,2,4,6,8$ and 10 hours after delivery of the treatments in morning meal (T0, T1, T2, T3, T4, $\mathrm{T} 5$ and T6, respectively).

The serum sample was used for dosing of albumin and total serum proteins. The plasma sample was used for urea dosing, with subsequent calculation of plasma urea nitrogen (PUN) multiplying the plasma urea concentration by 0.46 , as the nitrogen content in a molecule of urea is $46 \%$ (Lira et al., 2013).

Also, on the 21 st day of each period, urine spot samples were collected from the same 15 cows per group through vulvar stimulation after at least four hours of the morning meal. Then they were acidified to $\mathrm{pH} \leq 3$ to avoid degradation of the purine derivatives and subsequently diluted in a proportion of 1:4 with distilled water, after that frozen at $20{ }^{\circ} \mathrm{C}$ for further analysis of allantoin using a colorimetric method adapted from Chen and Gomes (1992). An aliquot of the sample without acidification was frozen in microtubes at $-20 \mathrm{C}$ for creatinine and urea dosages.
The allantoin:creatinine ratio was used as the predictor of intestinal absorption of $\mathrm{N}$ from microbial protein (Neal et al., 2014). The urinary urea results were multiplied by 0.46 for the urinary $N$ urine values to be found.

The daily urine production was estimated based on the urinary creatinine concentration of the spot samples in $\mathrm{mg}^{\mathrm{L}} \mathrm{L}^{-1}$, divided by the total daily creatinine excretion, which was obtained by multiplying the live weight by 29.0, a value found as a constant of creatinine excretion by Valadares et al. (1999). Urine production values in ${\mathrm{L} . \mathrm{d}^{-1}}^{-1}$ were used to calculate the total excretions of urinary $\mathrm{N}$ and allantoin in $\mathrm{g}^{-\mathrm{d}^{-1}}$ and mmol.d $\mathrm{d}^{-1}$, respectively.

For blood, creatinine and urine urea analyzes, commercial kits (Labtest Diagnóstica $S / A^{\circledR}$ ) were used. The analyses were read in semi-automatic biochemistry equipment (QuickLab - DRAKE ${ }^{\circledR}$ ).

The weighing and the evaluation of body condition score (BCS) were performed on the 21 st day of each period, and a scale of 1 to 5 with fractions of 0.25 was used (Wildman et al., 1982). The final value was a simple mean of the evaluations of two trained and independent evaluators.

Feed samples (corn silage, grass hay, commercial concentrate, wet brewery grains, soybean meal, ground corn and soybean hulls) were collected at the beginning of the trial for chemical analysis, and the results were used to calculate the ration.

The basal TMR was sampled weekly and at each 21-day period a composite sample of three weeks was formed for further analysis of DM, crude protein, fiber neutral detergent, fiber in acid detergent, ethereal extract, ash, calcium, phosphorus and the calculation of non-fibrous carbohydrates (NFC) (AOAC, 1995). The DM of the corn silage was analyzed weekly with the use of a KOSTER ${ }^{\circledR}$ and the DM of the TMR was adjusted.

\section{Statistical analysis}

Statistical analysis of milk production and composition data was performed using PROC MIXED (Littell et al., 2006) of the statistical package SAS ${ }^{\circledR}$ Studio 3.5 (SAS Institute, 2016), with the following model:

$Y i j k l=\mu+C i+B j+T k+P l+E i j k l$

Yijkl is the dependent variable, $\mu=$ average overall, $\mathrm{Ci}=$ effect of the covariate period, $\mathrm{Bj}=$ block effect $(j$ 
$=1$ to 15$), T k=$ treatment effect ( $\mathrm{j}=1$ to 3 ), $\mathrm{Pl}=$ period effect $(I=1$ to 3$)$ and eijkl = residual error.

Data on blood and urinary biochemistry were analyzed using PROC GLM with the same statistical software, the model used was:

$Y_{i j k}=\mu+V i+T j+P k+T^{*} P k+E i j k$

Yijk is the dependent variable, $\mu=$ average overall, $\mathrm{Vi}=$ cow effect $(\mathrm{i}=1$ to 45$), \mathrm{Tj}=$ treatment effect $(\mathrm{j}=$ 1 to 3$), P k=$ period effect $(I=1$ to 3$), \mathrm{Tj}^{\star} \mathrm{Pk}=$ effect of treatment interaction and period, and eijk $=$ residual error.

The comparisons between the averages of all variables were performed using the Tukey test, and the contrasts SMxCU, SMxPU and CUxPU were characterized.

\section{Results and discussion}

\section{Dietary effects on milk yield and composition}

The results of milk yield $\left(\mathrm{kg}^{\mathrm{d}} \mathrm{d}^{-1}\right), 3.5 \%$ fat corrected milk (FCM) and energy-corrected milk (ECM) did not present significant differences $(p>0.05)$ among treatments (Table 4). This result indicate that the different treatments were capable to sustain the milk yield regardless the partial differences in protein sources. This occurred due to the fact that when soybean meal was partially replaced, the space in the diet was occupied by ground corn maintaining the diets isonitrogenated and isocaloric.

Similar results were found by Santos et al. (2011), by partially replacing soybean meal with about $0.6 \%$ of encapsulated urea or conventional urea in DM matter basis of a lactating cows diet. These authors reported a maintenance in milk production together with a lower dry matter intake (DMI), demonstrating an increase in feed efficiency of $1.344 \mathrm{~kg}$ in the control group to $1.396 \mathrm{~kg}$ in the group with encapsulated urea.

A similar behavior was observed by Giallongo et al. (2015), who compared lactating cows diets with and without inclusion of $0.4 \%$ encapsulated urea and both with deficiency in metabolizable protein (MP) (according to the requirements of NRC, 2001), and did not find differences in milk yield and in ECM.

Both papers cited above used energy sources at different levels between diets with and without urea. In the present study fine ground corn was used to adjust DM of diets containing protected or conventional urea and, as commented, this adjust was able to maintain the same energy level of the SM diet.

Agle et al. (2010), comparing diets using encapsulated urea but with different inclusions of ground corn, observed that the increase of energy by starch significantly decreased the concentration of rumen ammonia and consequently improved the efficiency in the use of $(N)$ for the synthesis of milk, since daily yields were 36.0 and $33.2 \mathrm{~kg}^{\text {. day }}{ }^{-1}$ of milk yield in the diet with higher and lower corn inclusion, respectively.

However, the addition of starch in diets of dairy cows should be cautious, because in the same work cited previously (Agle et al., 2010) there was a depression in the content (\%) and production ( $\mathrm{kg}$. day $^{-1}$ ) of milk fat, as well as a drop in the $4.0 \%$ FCM. This clearly showed a negative effect on the ruminal environment and consequently depression on fat synthesis by the mammary gland (Bauman et al. 2008), maybe caused by a reduction o ruminal $\mathrm{pH}$.

Other authors that studied the replacement of soybean meal by protected urea also found no significant differences in milk yield (Souza et al., 2010) and in milk yield and milk solids production (kg.d ${ }^{-1}$ ) (Golombeski et al., 2006). Neal et al. (2014), as well, have not found significant differences in FCM and ECM when adding $0.49 \%$ of protected urea to the diet of lactating cows.

In relation to the inclusion of conventional urea, studies show that inclusions of about $1.9 \%$ of dietary DM (Brito and Broderick, 2007; Gonçalves et al., 2014), that is, above the recommended levels, can lead to lower DMI and lower milk yield, in addition to smaller FCM and ECM, decreasing the productive efficiency of the animals as a whole.

Oliveira et al. (2004), using three different levels of inclusion of conventional urea based on dietary DM $(0.70,1.40$ and $2.10 \%)$ of lactating cows, also found significant falls in DMI at levels above $1 \%$, however, the $3.5 \%$ FCM did not show a decrease in these same treatments.

Galo et al. (2003), however, when comparing the performance of cows receiving diets with $0.3 \%$ of conventional urea or $0.7 \%$ of protected urea in dietary DM, did not find significant differences in milk yield and DMI. The authors attributed these results to a possible loss of urea protection due to physical damage of the protective layer during diet processing. 
Table 4 - Results of milk yield and composition of the different experimental groups, in mean values per treatment

\begin{tabular}{|c|c|c|c|c|c|c|c|}
\hline \multirow{2}{*}{ Parameters $\left(\mathrm{kg} \cdot \mathrm{d}^{-1}\right)$} & \multicolumn{3}{|c|}{ Experimental diets } & \multirow{2}{*}{ SEM } & \multicolumn{3}{|c|}{$p$ values } \\
\hline & SM & $\mathrm{CU}$ & PU & & $\mathrm{SM} \times \mathrm{CU}$ & $\mathrm{SM} \times \mathrm{PU}$ & $\mathrm{CU} \times \mathrm{PU}$ \\
\hline Milk production & 34.03 & 33.86 & 33.49 & 0.36 & 0.95 & 0.57 & 0.78 \\
\hline FCM & 32.31 & 31.50 & 31.83 & 0.36 & 0.42 & 0.69 & 0.79 \\
\hline ECM & 32.76 & 32.05 & 32.24 & 0.34 & 0.48 & 0.63 & 0.93 \\
\hline Fat & 1.08 & 1.03 & 1.06 & 0.01 & 0.25 & 0.76 & 0.36 \\
\hline Protein & 1.05 & 1.04 & 1.03 & 0.01 & 0.88 & 0.46 & 0.64 \\
\hline Casein & 0.82 & 0.81 & 0.80 & 0.00 & 0.90 & 0.48 & 0.64 \\
\hline Lactose & 1.56 & 1.55 & 1.53 & 0.01 & 0.98 & 0.58 & 0.72 \\
\hline Total solids & 4.02 & 3.96 & 3.95 & 0.04 & 0.63 & 0.56 & 1.00 \\
\hline \multicolumn{8}{|l|}{ Levels in \% } \\
\hline Fat & 3.23 & 3.10 & 3.19 & 0.03 & 0.26 & 0.87 & 0.39 \\
\hline Protein & 3.13 & 3.12 & 3.11 & 0.01 & 0.90 & 0.55 & 0.87 \\
\hline Casein & 2.45 & 2.45 & 2.43 & 0.01 & 0.97 & 0.62 & 0.78 \\
\hline Lactose & 4.57 & 4.57 & 4.58 & 0.01 & 0.98 & 0.68 & 0.85 \\
\hline Total solids & 11.89 & 11.74 & 11.82 & 0.04 & 0.17 & 0.74 & 0.44 \\
\hline SCS & 3.11 & 3.16 & 3.01 & 0.10 & 0.92 & 0.80 & 0.63 \\
\hline MUN (mg.dL-1) & 15.82 & 16.56 & 16.66 & 0.30 & 0.27 & 0.23 & 0.97 \\
\hline $\operatorname{MUN}\left(g \cdot d^{-1}\right)$ & 5.41 & 5.68 & 5.58 & 0.12 & 0.37 & 0.71 & 0.81 \\
\hline Energy (Mcal.d ${ }^{-1}$ ) & 22.01 & 21.51 & 21.65 & 0.24 & 0.44 & 0.61 & 0.90 \\
\hline
\end{tabular}

Note: $\mathrm{SM}=$ treatment without replacement of soybean meal; $\mathrm{CU}=$ treatment with partial replacement of soybean meal by conventional livestock urea; PU = treatment with partial replacement of soybean meal with protected urea; $\mathrm{SEM}=\mathrm{stand}$ error mean; FCM = milk yield corrected to $3.5 \%$ fat; ECM = energy-corrected milk yield; SCS = somatic cell score by logarithmic transformation; MUN = milk urea nitrogen.

Some mechanisms may be involved in the DMI drop due to urea ingestion, but the decrease by low palatability of urea does not appear to be an important factor in this when animals receive encapsulated urea mixed in a TMR (Santos et al., 2011). There are studies showing that intraruminal infusions of urea negatively affect the DMI, leading to belief that there are systemic depressor mechanisms (Wilson et al., 1975). These mechanisms seem to be related to acidification of epithelial cells when they absorb large amounts of rumen ammonia (Visek, 1968), thus causing a decrease in ruminal motility (Antonelli et al., 2004) and consequently lower DMI (Juhász and Szegedi, 1983).

In the present study, there were no significant differences $(p>0.05)$ in milk fat content and yield among treatments (Table 4), indicating that the larger amount of fine ground corn added to diets with urea did not compromise the ruminal $\mathrm{pH}$, an important factor to reduce milk fat synthesis and content. These results differ in part from Souza et al. (2010) that, when adding protected urea $(0.4 \% \mathrm{DM})$ in partial substitution of soybean meal, found a decrease only in the percentage content of milk fat and not in the yield ( $\mathrm{kg}$.day ${ }^{-1}$ ) of this component.

Silveira et al. (2012) obtained different results from those observed in this study. They found a reduction in milk fat content from 3.82 to 3.75 by adding protected urea ( $7.5 \%$ of the original matter) and fine ground corn in partial replacement to soybean meal in lactating cows diet.

Santos et al. (2011) worked with diets containing conventional urea or protected urea replacing soybean meal and did not find differences in milk fat production, but the authors did not compare the two types of urea. Broderick and Reynal (2009) also found no difference in milk fat content and yield when conventional urea levels were included varying from 0.41 to $1.31 \%$ of DM.

There are authors that cite a possible increase in milk fat with the use of protected urea in the diet of 
lactating cows (Highstreet et al., 2010). This would occur due to a stabilization of the ruminal fermentation and consequently change in the profile of short chain fatty acids (SCFA) absorbed by the animal.

Daily yields and level of protein, casein, lactose and total milk solids did not show significant differences $(p>0.05)$ among treatments in the present study (Table 4). Consequently, the energy excretion in milk in Mcal.kg.d ${ }^{-1}$ was not affected by the different treatments.

These results corroborate the results obtained by Santos et al. (2011), Silveira et al. (2012) and Inostroza et al. (2010) that did not report differences in these parameters. However, Souza et al. (2010) obtained a significant difference in milk solids content when protected urea partially replaced soybean meal in the diet.

When Highstreet et al. (2010) compared conventional urea to fat-protected urea, significant decreases in milk fat, protein, and total milk yields were found in animals receiving conventional urea. These results negatively affected the energy excreted in milk, which was also lower in this group (131.8 x

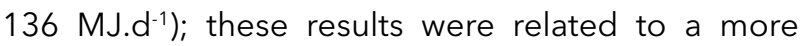
stable ruminal fermentation when protected urea was used, with smaller and shorter ammonia peaks.

Broderick and Reynal (2009) found a decrease of only $0.05 \mathrm{~kg}$ in daily milk protein yield when animals received $0.41 \%$ of conventional urea in dietary DM. This decrease was higher with the increasing levels of 0.84 and $1.31 \%$ of conventional urea. The bigger inclusion level also negatively affected lactose production in $\mathrm{kg}^{\mathrm{d}} \mathrm{d}^{-1}$, but these differences were not found in the contents of both components (protein and lactose).

There was no significant difference $(p>0.05)$ in SCS values between the groups. It showed that there were no significant differences in mammary gland health status of the cows, and it did not compromise milk and milk components yields due to this factor.

The values of MUN (mg.dL-1 and g.d $\mathrm{d}^{-1}$ ) and casein contents did not show a significant difference $(p>$ 0.05 ) between groups (Table 4), demonstrating that the use of $\mathrm{N}$ by ruminal bacteria was similar between the different treatments. The use of finely ground corn instead of other feed like soybean hulls and citric pulp in partial replacement of soybean meal, certainly contributed to a better ruminal usage of $\mathrm{N}$, and it is due to the greater ruminal fermentability of starch in corn than the neutral detergent fiber from soybean hulls and pectin from citrus pulp.

Aquino et al. (2009) also found no differences in casein and urea levels in the milk of cows fed 0.75 and $1.50 \%$ of conventional urea to replace soybean meal in a DM basis. According to these authors, there are no losses in the industrial milk yield of cows fed with urea inclusions at levels up to $1.50 \%$ of TMR dry matter, since the absolute amounts and also the relationships between these milk components did not vary.

Highstreet et al. (2010) did not observe differences in the MUN levels among cows in the initial third of lactation receiving conventional urea or protected urea. However, there was an increase in MUN of the milk of cows in the middle third of lactation receiving conventional urea, a result that differs from the present study.

Silveira et al. (2012) found no difference in MUN only when protected urea was added to the diet of dairy cows with inclusion of ground corn, however, when the addition was accompanied by corn silage, MUN levels varied between groups. These results are in agreement with those obtained by Santos et al. (2011), that reported higher levels of MUN when the animals were fed conventional urea with citrus pulp, compared to a control group. This demonstrates that when urea is used with sources of less rumen availability of energy and with less starch when compared to fine ground corn, there may be less ammonia use and greater $\mathrm{N}$-escape of rumen as ammonia.

Another factor that may have contributed to the similarity of the MUN results between the treatments is the similar level of CP among the treatments. It was demonstrate that $\mathrm{CP}$ content is the main factor related to variations in MUN (Hof et al., 1997; Aguilar et al., 2012). In addition, the recycling of $N$ in ruminants seems to be an important mechanism for the reuse of this $\mathrm{N}$ by ruminal bacteria (Reynolds and Kristensen 2008), which may explain the absence of differences $(p>0.05)$ in MUN.

The results of milk production and composition demonstrate that urea protected by protein nanoparticles can maintain a rumen environment suitable for ruminal microorganisms, without affecting the digestibility of feed, for example.

Conventional urea when supplied with sufficient amounts of starch sources also maintained the proper ruminal environment in the present study, probably maintaining bacterial multiplication at adequate 
levels for good digestibility of feed. This is due to the fact that energy in the form of starch is the most important dietary factor in the efficiency and intensity of rumen protein synthesis (Agle et al., 2010).

\section{Dietary effects on urinary parameters and blood biochemistry}

No significant differences were found $(p>0.05)$ in the results of live weight, serum proteins, albumin, urinary urea and urine production between groups (Table 5).

The results of serum proteins and albumin are similar to those found by Calomeni et al. (2015), when providing urea with two types of encapsulation, the authors did not find differences in the comparison of both ureas with the control and with the conventional urea. Taking into account that blood proteins may contribute about 15 to $40 \%$ of the total proteins synthesized in hepatic tissue (Kozloski, 2011), it can be seen that both ureas did not affect the metabolism of amino acids in the liver, maintaining an adequate MP use and consequently adequate protein synthesis.

The results of urine production seem to be overestimated, since several studies with diets and cows of similar weights and productions to the present study demonstrate significantly smaller urinary productions (Broderick, 2003; Broderick \& Reynal, 2009; Santos et al., 2011). However, Valadares et al. (1999) reported similar urinary output (about 47 $\mathrm{L.d}^{-1}$ ) using the same constant of creatinine excretion (29 $\mathrm{mg} \cdot \mathrm{kg}^{-1}$ of LBW).

Table 5 - Results of blood biochemistry, parameters and urinary estimates and weight of the animals of the different experimental groups, in mean values per treatment

\begin{tabular}{|c|c|c|c|c|c|c|c|}
\hline \multirow{2}{*}{ Parameters (mg.dL-1) } & \multicolumn{3}{|c|}{ Experimental diets } & \multirow{2}{*}{ SEM } & \multicolumn{3}{|c|}{$p$ values } \\
\hline & SM & $\mathrm{CU}$ & PU & & $\mathrm{SM} \times \mathrm{CU}$ & $\mathrm{SM} \times \mathrm{PU}$ & $\mathrm{CU} \times \mathrm{PU}$ \\
\hline Total protein & 7.66 & 7.63 & 7.56 & 0.05 & 0.95 & 0.54 & 0.73 \\
\hline Albumin & 2.78 & 2.74 & 2.80 & 0.02 & 0.37 & 0.81 & 0.13 \\
\hline Urinary creatinine & 44.69 & 42.14 & 47.88 & 1.62 & 0.71 & 0.58 & 0.16 \\
\hline Urinary urea & 1189.26 & 1199.22 & 1306.93 & 52.53 & 0.99 & 0.47 & 0.51 \\
\hline \multicolumn{8}{|l|}{ Daily excretions } \\
\hline Urinary creatinine (mmol) & 144.41 & 144.33 & 144.58 & 1.23 & 0.96 & 0.84 & 0.66 \\
\hline Urinary urea (g) & 500.76 & 534.43 & 573.44 & 22.05 & 0.80 & 0.35 & 0.73 \\
\hline Urine production $(\mathrm{L})$ & 57.38 & 58.44 & 49.76 & 3.10 & 0.98 & 0.33 & 0.22 \\
\hline Urinary N-ureic ${ }^{1}$ (g) & 231.31 & 246.17 & 263.78 & 10.14 & 0.81 & 0.38 & 0.73 \\
\hline Live body weight (kg) & 679.57 & 678.86 & 679.86 & 5.81 & 0.86 & 0.97 & 0.74 \\
\hline
\end{tabular}

Note: $\mathrm{SM}=$ treatment without replacement of soybean meal; $\mathrm{CU}=$ treatment with partial replacement of soybean meal by conventional urea; $\mathrm{PU}=$ treatment with partial replacement of soybean meal with protected urea; SEM = standard error mean. ${ }^{1}$ Urinary urea $\times 0.466$.

Highstreet et al. (2010) worked with conventional or protected urea fed to cows in the initial third or middle third of lactation and found estimated urine productions close to the present study, with yields of 47.3 and 48.6 L.d $^{-1}$ for the group with conventional urea and 46.4 and $45.2 \mathrm{~L}^{-d^{-1}}$ for the protected urea group, for cows from the initial and medium third lactation, respectively.

The values of ureic $\mathrm{N}$ excreted daily by the urine did not differ significantly between the groups (Table 5).
The reduction of nitrogen excretion via urine demonstrates a positive correlation with a lower fecal N excretion (Hristov et al., 2011; Lee et al., 2012). This information shows that the treatments appeared to be the same from the point of view of environmental impact, since these two ways of excretion are the most important to the environment, furthermore the recycling of $N$ apparently influenced this result, providing greater chances of $\mathrm{N}$ being used by ruminal microorganisms instead of being excreted. 
Broderick and Reynal (2009), using different levels of conventional urea in the diet of lactating cows ( 0.41 to $1.31 \%$ of DM), observed higher levels of ureic $\mathrm{N}$ excretion in the lower urine production. The same behavior was found by Giallongo et al. (2015) when comparing two MP deficient diets, one of them with $0.4 \%$ protected urea on DM basis.

Galo et al. (2003) reported higher ureic N excretions in the urine of cows receiving protected urea compared to the urea-free group. These authors attributed the higher excretion of $\mathrm{N}$ in the urine due to a lower use of $\mathrm{N}$ by ruminal bacteria, but the higher excretions of $\mathrm{N}$ in the urine were found together with higher urine production, a result that differs from those found in the present study.

The results of urinary allantoin did not differ $(p>0.05)$ between the treatments (Table 6), demonstrating that there were no differences in the synthesis and absorption of microbial protein (Pmic) between the treatments. This result is aligned with others like milk and milk components yield, and MUN, that showed no differences in the present study, demonstrating that the ruminal environment was kept stable and with sufficient substrates for microbial multiplication, with consequent adequate Pmic synthesis and absorption as MP.

Table 6 - Results related to urinary allantoin and microbial protein synthesis

\begin{tabular}{|c|c|c|c|c|c|c|c|}
\hline \multirow{2}{*}{ Parameters } & \multicolumn{3}{|c|}{ Experimental diets } & \multirow{2}{*}{ SEM } & \multicolumn{3}{|c|}{$p$ values } \\
\hline & SM & CU & PU & & $\mathrm{SM} \times \mathrm{CU}$ & $\mathrm{SM} \times \mathrm{PU}$ & $\mathrm{CU} \times \mathrm{PU}$ \\
\hline Allantoin (mmol.L-1) & 10.77 & 10.34 & 10.80 & 0.37 & 0.86 & 0.42 & 0.18 \\
\hline Allantoin (mmol.d $\left.\mathrm{d}^{-1}\right)$ & 521.02 & 536.34 & 562.13 & 26.64 & 0.97 & 0.82 & 0.92 \\
\hline Allantoin:creatinine & 3.01 & 3.10 & 3.17 & 0.15 & 0.97 & 0.91 & 0.98 \\
\hline
\end{tabular}

Note: $\mathrm{SM}=$ treatment without replacement of soybean meal; $\mathrm{CU}=$ treatment with partial replacement of soybean meal by conventional urea; $\mathrm{PU}=$ treatment with partial replacement of soybean meal with protected urea; SEM = standard error mean.

The evaluation of the excretion of purine derivatives in the urine provides reliable estimates of the production of microbial protein in the rumen, since the main derivative excreted in the urine of cattle is allantoin (Valadares et al., 1999). Neal et al. (2014) demonstrated that the allantoin:creatinine ratio can be used successfully for this purpose.

Santos et al. (2011) found no differences in the allantoin:creatinine ratio and in the daily excretion of allantoin in mmol.d-1 in dairy cows fed with protected urea. The same result was observed by $\mathrm{Neal}$ et al. (2014) who added $0.49 \%$ of protected urea instead of a soybean meal and canola meal; this substitution did not increase significantly these parameters. However, Galo et al. (2003), comparing the supplying of conventional urea or protected urea to lactating cows, found no differences in the excretions in $\mathrm{mmol}^{-\mathrm{d}^{-1} \text { of }}$ purine derivatives.

The peak of PUN found in all the treatments occurred around on four to six hours after the morning meal. This result is similar to that described by Highstreet et al. (2010) who reported that plasma urea peak usually occurs between one and four hours after ingestion.
Santos et al. (2011) found PUN peaks about two hours after morning intake of conventional urea or protected urea. These authors also cite that the PUN peak was not found in the afternoon feeding, probably due to the lower ruminal $\mathrm{pH}$ and also to the peak of carbohydrate degradation, both occurring in that period (Salvador et al., 2008).

The ruminal $\mathrm{pH}$ directly influences the behavior of ammonia absorption by the rumen epithelium. At a pH close to neutrality, the unprotonated form is in higher proportion; this form also presents higher absorption rates than the protonated form, which is present in a higher proportion in acidic $\mathrm{pH}$ (Abdoun et al., 2006), which probably contributed to the MUN values did not change between the groups, even with higher PUN values in the treatments with both ureas. Regardless of the ruminal $\mathrm{pH}$ and peak time of PUN, the higher PUN concentrations of the PU and $\mathrm{CU}$ treatments at most sampling times indicate that there was greater ruminal $\mathrm{N}$ escape compared to SM, however this greater escape did not lead to a greater urinary loss or even an increase in MUN, as these variables did not differ between treatments. This result is potentially explained by the intense recycling 
of $\mathrm{N}$ in ruminants, a characteristic that is essential for a better efficiency in the use of this nutrient.

The PUN values found in the different groups presented significant differences $(p<0.05)$ at 0,4 , 6,8 and 10 hours after the morning meal (Figure 1). At T0, the highest PUN value $(p<0.01)$ was found

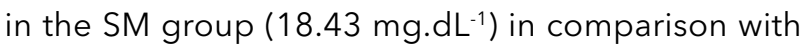

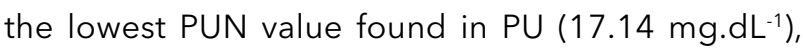
however after four hours of the morning feeding, the behavior of PUN in the SM treatment started to change in relation to $\mathrm{CU}$ and $\mathrm{PU}$, with the $\mathrm{SM}$ group showing the lowest PUN values in T3 $\left(20.36 \mathrm{mg}^{-\mathrm{dL}^{-1}}\right)$, T4 (20.37 mg.dL-1), T5 (19.49 mg.dL-1) and T6 (18.99 mg.dL-1), while CU showed highest levels of PUN in these sampling times $(21.92,22.13,21.46$ and 21.49 $\mathrm{mg} \cdot \mathrm{dL}^{-1}$, respectively).

The PUN group showed no difference $(p>0.05)$ in times T3 (20.08 mg.dL-1) and T4 (21.68 mg. dL-1), but in sampling times $\mathrm{T} 5\left(21.43 \mathrm{mg}^{-\mathrm{dL}^{-1}}\right)$ and $\mathrm{T} 6$ (21.72 mg.dL-1) PU showed the same pattern of CU, differing $(p<0.01)$ from SM in both times. At all the sampling times the PUN values for $\mathrm{CU}$ and PU groups were equal $(p>0.05)$.

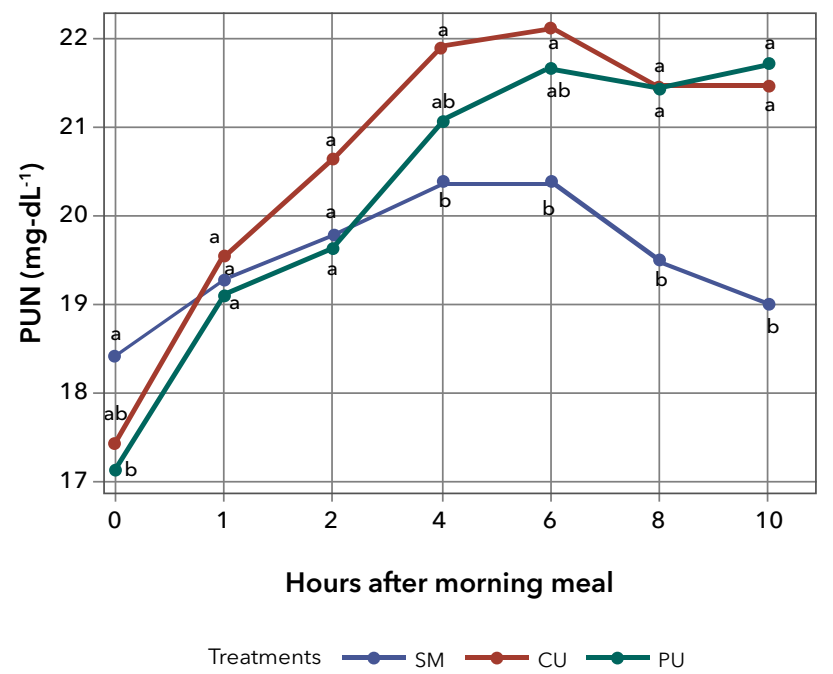

Figure 1 - Graph of the PUN values of the different treatments (SM, CU, PU) in the different sampling times after the morning meal.

Note: PUN = plasma ureic nitrogen in mg.dL-1; $\mathrm{SM}=$ treatment without replacement of soybean meal; $\mathrm{CU}=$ treatment with partial replacement of soybean meal by conventional urea; $\mathrm{PU}=$ treatment with partial replacement of soybean meal with protected urea. Different letters at the same collection time differ significantly between treatments $(p<0.05)$.
These differences are related to the greater escape of ruminal ammonia in the treatments $\mathrm{CU}$ and $\mathrm{PU}$, indicating that the protection with protein nanoparticle was unable to efficiently slow down the urea degradation in ammonia, since the behavior of PUN was almost the same between CU and PU. This greater ruminal escape of $\mathrm{N}$ in the form of ammonia induce to a greater synthesis of urea by the liver, thus increasing PUN concentrations.

\section{Conclusion}

The addition of up to $0.59 \%$ of nanoparticleprotected urea and $0.52 \%$ of conventional urea in the DM of the TMR of lactating cows does not alter milk yield and composition, as well as urinary variables in these animals as long as this inclusion of urea is carried out in combination with finely ground corn or another starch source with good digestibility, thus maintaining a suitable ruminal environment for adequate microbial multiplication, with consequent good digestion of the diet and a good milk production.

From the standpoint of ammonia absorption in the rumen, protection of urea by protein nanoparticles was not able to decrease the rate of absorption. This is evidenced due to the similar PUN results for the $\mathrm{CU}$ and PU groups.

\section{Acknowledgements}

The authors would like to thank CAPES (Coordination for the Improvement of Higher Education Personnel) for the scholarship granted to the students involved in this trial, as well as the Pontifícia Universidade Católica do Paraná and Sion Nanotec S.A. for funding this research and providing the products used.

\section{References}

Abdoun K, Stumpff F, Martens H. Ammonia and urea transport across the rumen epithelium: a review. Anim Health Res Rev. 2006;7(1-2):43-59.

Agle M, Hristov AN, Zaman S, Schneider C, Ndegwa PM, Vaddella VK. Effect of dietary concentrate on rumen fermentation, digestibility, and nitrogen losses in dairy cows. J Dairy Sci. 2010;93(9):4211-22. 
Aguilar M, Hanigan MD, Tucker HA, Jones BL, Garbade SK, McGilliard $M L$, et al. Cow and herd variation in milk urea nitrogen concentrations in lactating dairy cattle. J Dairy Sci. 2012;95(12):7261-8.

Antonelli AC, Mori CS, Soares PC, Kitamura SS, Ortolani EL. Experimental ammonia poisoning in cattle fed extruded or prilled urea: clinical findings. Braz J Vet Res Anim Sci. 2004;41(1):67-73.

Aquino AA, Peixoto Jr KC, Gigante ML, Rennó FP, Prada e Silva LF, Santos MV. Efeitos de níveis crescentes de uréia na dieta de vacas leiteira sobre a composição e rendimento de fabricação de queijos minas frescal. Braz J Vet Res Anim Sci. 2009;46(4):273-9.

AOAC. Official methods of analysis. 16th ed. Washington: Association of official analytical chemists; 1995.

Bauman DE, Perfield JW, Harvatine KJ, Baumgard LH. Regulation of fat synthesis by conjugated linoleic acid: Lactation and the ruminant model. J Nutr. 2008;138(2):403-9.

Boerman JP, Potts SB, VandeHaar MJ, Lock AL. Effects of partly replacing dietary starch with fiber and fat on milk production and energy partitioning. J Dairy Sci. 2015;98(10):7264-76.

Brito AF, Broderick GA. Effects of different protein supplements on milk production and nutrient utilization in lactating dairy cows. J Dairy Sci. 2007;90(4):1816-27.

Broderick GA. Effects of varying dietary protein and energy levels on the production of lactating dairy cows. J Dairy Sci. 2003;86(4):1370-81.

Broderick GA, Reynal SM. Effect of source of rumen-degraded protein on production and ruminal metabolism in lactating dairy cows. J Dairy Sci. 2009;92(6):2822-34.

Calomeni GD, Gardinal R, Venturelli BC, Freitas Jr JE, Vendramini THA, Takiya CS, et al. Effects of polymer-coated slow-release urea on performance, ruminal fermentation, and blood metabolites in dairy cows. R Bras Zootec. 2015;44(9):327-34.

Chen XB, Gomes MJ. Estimation of microbial protein supply to sheep and cattle based on urinary excretion of purine derivatives - An overview of the technical details. Bucksburn: International Feed Research Unit; 1992.

Galo E, Emanuele SM, Sniffen CJ, White JH, Knapp JR. Effects of a polymer-coated urea product on nitrogen metabolism in lactating holstein dairy cattle. J Dairy Sci. 2003;86(6):2154-62.
Gabarra PR. Digestibilidade de nutrientes e parâmetros ruminais e sanguíneos de novilhos Nelore alimentados com fontes proteicas e energéticas com diferentes degradabilidades ruminais [dissertação]. Piracicaba: Universidade de São Paulo; 2001. 109 p.

Giallongo F, Hristov AN, Oh J, Frederick T, Weeks H, Werner $J$, et al. Effects of slow-release urea and rumen-protected methionine and histidine on performance of dairy cows. J Dairy Sci. 2015;98(5):3292-308.

Golombeski GL, Kalscheur KF, Hippen AR, Schingoethe DJ. Slow-release urea and highly fermentable sugars in diets fed to lactating dairy cows. J Dairy Sci. 2006;89(11):4395-403.

Gonçalves GS, Pedreira MS, Azevedo JAG, Del Rei AJ, Silva HGO, Silva FF. Replacement of soybean meal by conventional and coated urea in dairy cows: intake, digestibility, production and composition of milk. Acta Sci Anim Sci. 2014;36(1): $71-8$.

Highstreet A, Robinson PH, Robison J, Garrett JG. Response of holstein cows to replacing urea with a slowly rumen released urea in a diet high in soluble crude protein. Livest Sci. 2010;129(1-3):179-85.

Hof G, Vervoorn MD, Lenaers PJ, Tamminga S. Milk urea nitrogen as a tool to monitor the protein nutrition of dairy cows. J Dairy Sci. 1997;80(12):3333-40.

Hristov AN, Hanigan M, Cole A, Todd R, McAllister TA, Ndegwa PM, et al. Review: Ammonia emissions from dairy farms and beef feedlots. Can J Anim Sci. 2011;91(1):1-35.

Inostroza JF, Shaver RD, Cabrera VE, Tricárico JM. Effect of diets containing a controlled release urea product on milk yield, milk composition, and milk component yields in commercial Wisconsin dairy herds and economic implications. Prof Anim Sci. 2010;26(2):175-80.

Juhász B, Szegedi B. Effects of disturbances of acid-base equilibrium on the activity of the rumen. Acta Physiol Hung. 1983;62(1):7-17.

Kozloski GV. Bioquímica dos ruminantes. 3rd ed. Santa Maria: Universidade Federal de Santa Maria; 2011.

Lapierre H, Lobley GE. Nitrogen recycling in the ruminant: A review. J Dairy Sci. 2001;84(E. Suppl.):E223-36. 
Lee C, Hristov AN, Dell CJ, Feyereisen GW, Kaye J, Beegle D. Effect of dietary protein concentration on ammonia and greenhouse gas emitting potential of dairy manure. J Dairy Sci. 2012;95(4):1930-41.

Lira FRA, Oliveira VS, Santos GRA, Silva MA, Oliveira AG, Goveia JSS. Monitoramento protéico em rebanhos de vacas leiteiras em Sergipe. Semina Cienc Agrar. 2013;34(6):3043-56.

Littell RC, Milliken GA, Stroup WW, Wolfinger RD, Schabenberger O. SAS ${ }^{\circledR}$ for Mixed Models. Cary, NC: SAS Institute Inc.; 2006.

Mutsvangwa T, Davies KL, McKinnon JJ, Christensen DA. Effects of dietary crude protein and rumen-degradable protein concentrations on urea recycling, nitrogen balance, omasal nutrient flow, and milk production in dairy cows. J Dairy Sci. 2016;99(8):6298-310.

National Research Council (NRC). Nutrient requirements of dairy cattle. 7th ed. Washington: National Academy; 2001.

Neal K, Eun JS, Young AJ, Mjoun K, Hall JO. Feeding protein supplements in alfalfa hay-based lactation diets improves nutrient utilization, lactational performance, and feed efficiency of dairy cows. J Dairy Sci. 2014;97(12):7716-28.

Nelson DL, Cox MM. Lehninger principles of biochemistry. 4th ed. New York: W.H. Freeman; 2004.

Oliveira MMNF, Torres CAA, Valadares Filho SC, Santos $A D F$, Properi CP. Uréia para vacas leiteiras no pós-parto: desempenhos produtivo e reprodutivo. R Bras Zootec. 2004;33(6 Sup 3):2266-73.

Rajala-Shultz PJ, Saville WJA, Frazer GS, Wittum TE. Association between milk urea nitrogen and fertility in Ohio dairy cows. J Dairy Sci. 2001;84(2):482-9.

Reid JT. Urea as a protein replacement for ruminants: A review. J Dairy Sci. 1953;36(9):955-96.

Reynolds CK, Kristensen NB. Nitrogen recycling through the gut and the nitrogen economy of ruminants: an asynchronous symbiosis. J Anim Sci. 2008;86(14 Suppl):E293-305.

Rhoads ML, Rhoads RP, Gilbert RO, Toole R, Butler WR. Detrimental effects of high plasma urea nitrogen levels on viability of embryos from lactating dairy cows. Anim Reprod Sci. 2006;91(1-2):1-10.
Salvador SC, Pereira MN, Santo JF, Melo LQ, Chaves ML. Resposta de vacas leiteiras à substituição total de milho por poupa cítrica e à suplementação com microminerais orgânicos I: Consumo e digestão. Arq Bras Med Vet Zootec. 2008;60(3):682-90.

Santos GT, Cavalieri FLB, Modesto EC. Recentes avanços em nitrogênio não protéico na nutrição de vacas leiteiras. Anais do $2^{\circ}$ Simpósio Internacional em Bovinocultura de Leite: Novos conceitos em nutrição; Lavras, MG; 2001. p. 199-228.

Santos JF, Dias Jr GS, Bitencourt LL, Lopes NM, Siécola Jr S, Silva JRM, et al. Resposta de vacas leiteiras à substituição parcial de farelo de soja por ureia encapsulada. Arq Bras Med Vet Zootec. 2011;63(2):423-32.

SAS Institute. SAS User's Guide: Statistics. Version 3.5. Cary, NC: SAS Institute Inc.; 2016.

Silveira VA, Lopes NM, Oliveira RC, Gonzales B, Siqueira AV, Bier LPP, et al. Substituição parcial de farelo de soja por ureia de liberação lenta em rebanhos leiteiros comerciais. Rev Bras Saude Prod Anim. 2012;13(2):383-95.

Souza VL, Almeida R, Silva DFF, Piekarski PRB, Jesus CP, Pereira MN. Substituição parcial de farelo de soja por ureia protegida na produção e composição do leite. Arq Bras Med Vet Zootec. 2010;62(6):1415-22.

Spek JW, Dijkstra J, van Duinkerken G, Hendricks WH, Bannink A. Prediction of urinary nitrogen and urinary urea nitrogen excretion by lactating dairy cattle in northwestern Europe and North America: A meta-analysis. J Dairy Sci. 2013;96(7): 4310-22.

Valadares RFD, Broderick GA, Valadares Filho SC, Clayton MK. Effect of replacing alfalfa silage with high moisture corn on ruminal protein synthesis estimated from excretion of total purine derivatives. J Dairy Sci. 1999;82(12):2686-96.

Visek WJ. Some aspects of ammonia toxicity in animal cells. J Dairy Sci. 1968;51(2):286-95.

Wildman EE, Jones GM, Wagner PE, Boman RL, Troutt Jr HF, Lesch TN. A dairy cow body condition scoring system and its relationship to selected production characteristics. J Dairy Sci. 1982;65(3):495-501.

Wilson G, Martz FA, Campbell JR, Becker BA. Evaluation of factors responsible for reduced voluntary intake urea diets for ruminants. J Anim Sci. 1975;41(5):1431-7. 